\title{
Protein Interactions With Quaternized Chitosan/Heparin Multilayers
}

\author{
M. KUMOREK ${ }^{1}$, D. KUBIES ${ }^{1}$, T. RIEDEL ${ }^{1}$ \\ ${ }^{1}$ Institute of Macromolecular Chemistry of the Czech Academy of Sciences, Prague, Czech \\ Republic
}

Received July 14, 2016

Accepted July 14, 2016

\begin{abstract}
Summary
Understanding the behavior of single proteins at the polyelectrolyte multilayer film/solution interface is of prime importance for the designing of bio-functionalized surface coatings. In the present paper, we study the adsorption of the model proteins, albumin and lysozyme, as well as basic fibroblast growth factor (FGF-2) on a polysaccharide multilayer film composed of quaternized chitosan and heparin. Several analytical methods were used to describe the formation of the polysaccharide film and its interactions with the proteins. Both albumin and lysozyme adsorbed on quaternized chitosan/heparin films, however this process strongly depended on the terminating polysaccharide. Protein adsorption was driven mainly by electrostatic interactions between protein and the terminal layer of the film. The effective binding of FGF-2 by the heparinterminated film suggested that other interactions could also contribute to the adsorption process. We believe that this FGF-2presenting polysaccharide film may serve as a biofunctional surface coating for biologically-related applications.
\end{abstract}

\section{Key words}

Heparin • Chitosan - Protein • Basic fibroblast growth factor • Layer-by-layer

\section{Corresponding authors}

M. Kumorek and D. Kubies, Department of Bioactive Polymers, Institute of Macromolecular Chemistry of the Czech Academy of Sciences, Heyrovského nám. 2, 16206 Prague 6, Czech Republic. Fax: +420 296809 410. Email: kumorek@imc.cas.cz and kubies@imc.cas.cz

\section{Introduction}

Layer-by-layer (LbL) assembly is a simple method that enables the creation of versatile, robust, nanometer scale coatings on a variety of surfaces. Generally, the LbL fabrication process is performed in non-denaturing aqueous conditions, thus allowing for the incorporation of fragile biomolecules. The polyelectrolyte multilayer films functionalized with proteins, such as growth factors, are of great interest as bioactive surface coatings for biologically-related applications (Monge et al. 2015, Gribova et al. 2012). Recently, we reported on cross-linked albumin/heparin multilayer films for the immobilization of the basic fibroblast growth factor (FGF-2) (Kumorek et al. 2015).

Two polysaccharides, chitosan exhibiting an antimicrobial property (Wiarachai et al. 2012, Follmann et al. 2012), and heparin known as an anticoagulant and growth factor binding agent (Faham et al. 1996, Wang et al. 2014), have been extensively exploited to develop biofunctional multilayer films (Almodovar et al. 2010, Monge et al. 2015). However, the formation of the chitosan-based coatings can lead to some difficulties due to the limited solubility of chitosan above $\mathrm{pH}=6$ (Wiarachai et al. 2012). Furthermore, the LbL assembly of chitosan as a weak polycation with polyanions requires a very acidic $\mathrm{pH}$ to ensure an appropriate protonation of amino groups of chitosan (Almodovar et al. 2010). One way to improve the solubility of chitosan is the quaternization of amine groups. Such cationically modified chitosan exhibits good solubility over a broader $\mathrm{pH}$ range (Follmann et al. 2012). Furthermore, quaternized chitosan/heparin multilayers displayed an improved antibacterial property as compared to the native chitosan-based film (Follmann et al. 2012). Also, N, N, N-trimethyl chitosan with heparin in the form of polyelectrolyte complex nanoparticles demonstrated an efficient delivery system of growth factor (Volpato et al. 2012). 
Understanding the behavior of single proteins at the polyelectrolyte film/solution interface is of prime importance for designing bio-functionalized multilayer coatings. Depending on the application, one can select LbL films which enhance or reduce the adsorption of the specific biomolecules (Ariga et al. 2014). Protein interactions with LbL films depend on many factors, particularly on the charge of the protein and the terminating layer of film (Salloum and Schlenoff 2004). In the present paper, we study the adsorption of two model proteins of different isoelectric points, $\mathrm{I}_{p}$, i.e. albumin $\left(\mathrm{I}_{p}=4.9\right.$ (Salloum and Schlenoff 2004)) and lysozyme $\left(\mathrm{I}_{p}=11.4\right.$ (Salloum and Schlenoff 2004)) as well as FGF-2 $\left(\mathrm{I}_{p}=9.59\right.$ (Dephillips and Lenhoff 2004)) on a polysaccharide multilayer film composed of chitosan quaternized with glicidyltrimethylammonium chloride and heparin. The LbL films were terminated with quaternized chitosan or heparin. The surface plasmon resonance and UV-Vis spectroscopy were used to quantitatively describe the formation of polysaccharide LbL films and their interaction with proteins. Simultaneously, the qualitative surface information of quaternized chitosan/heparin LbL films with or without adsorbed protein was obtained by atomic force microscopy.

\section{Material and Methods}

\section{Materials}

Chitosan (Ch, LMW), heparin sodium salt from porcine intestinal mucosa (Hep, 17-19 kDa), glycidyltrimethylammonium chloride (GTMAC, $\geq 90 \%$ ), bovine serum albumin (Alb, $\geq 96 \%$ ), lysozyme from chicken egg white (Lys, $\geq 90 \%$ ), albumin-fluorescein isothiocyanate conjugate (Alb ${ }^{\text {FITC }}$, FITC:Alb molar ratio 10:1), fluorescein isothiocyanate isomer I (FITC, $\geq 90 \%$ ), 16-mercaptohexadecanoic acid (ACID-16, $99 \%$ ), phosphate buffer saline (PBS) were purchased from Sigma-Aldrich.

\section{The synthesis of cationically modified chitosan (CMCh)}

Chitosan was modified by GTMAC as described previously (Cho et al. 2006). Briefly, $2.5 \mathrm{~g}$ of Chitosan was dispersed in $100 \mathrm{ml}$ of distilled water containing $21 \mathrm{ml}$ of $0.5 \%$ acetic acid. After one hour of stirring, $6.9 \mathrm{ml}$ of GTMAC was added and the reaction was carried out at $55^{\circ} \mathrm{C}$ for $18 \mathrm{~h}$. The product was precipitated into acetone and isolated by centrifugation (6000 rpm for $5 \mathrm{~min}$ ). This process was repeated twice.
Afterward, the product was dissolved in water, dialyzed (Spectra/Por, cut off 6-8 $\mathrm{kDa}$ ) against distilled water for 2 days, and freeze-dried. The product was characterized with elemental analysis $(\mathrm{CMCh}, \mathrm{C} \%=41.88 ; \mathrm{H} \%=8.45$; $\mathrm{N} \%=7.83$ ). The reaction's occurrence was confirmed by ${ }^{1} \mathrm{H} \quad \mathrm{NMR} \quad\left(\mathrm{D}_{2} \mathrm{O} / \mathrm{CF}_{3} \mathrm{COOD}, \quad 300 \mathrm{MHz}\right): \quad \delta=3.2 \mathrm{ppm}$ corresponds to the protons of the ${ }^{-} \mathrm{N}\left(\mathrm{CH}_{3}\right)_{3}$ group of GTMAC, and FTIR: $1480 \mathrm{~cm}^{-1}$ assigned to an asymmetric angular bending of $\mathrm{C}-\mathrm{H}$ of $-\mathrm{CH}_{3}$ groups of GTMAC; the disappearance of the band at $1590 \mathrm{~cm}^{-1}$ assigned to vibrations of $\mathrm{N}-\mathrm{H}$ of the primary amino groups of Chitosan.

The degree of deacetylation (DDA) of Chitosan was $78.6 \%$ as calculated from elemental analysis data (Kasaai et al. 2000).

The degree of substitution (DS) of CMCh was obtained from conductometric titration of the $\mathrm{CMCh}$ aqueous solution with the $\mathrm{AgNO}_{3}$ solution according to (Cho et al. 2006) using a digital conductivity meter (Jenway, UK). The DS was calculated using the following equation:

$$
D S=\frac{1.7 \times 10^{-5} V_{A g N O_{3}}^{\prime}}{\left(\frac{W_{C M C h}-1.7 \times 10^{-5} V_{A g N O_{3}}^{*} m_{G T M A C}}{m_{G} D D A+(1-D D A) m_{A G}}\right) D D A} \times 100 \%
$$

where $\mathrm{W}_{\text {CMCh }}$ is the weight of CMCh in $10 \mathrm{ml}$ of the analyzed sample; $m_{\text {GTMAC }}$ is the molecular weight of GTMAC; $m_{\mathrm{G}}$ and $m_{\mathrm{AG}}$ are the molecular weights of glucosamine and acetylated glucosamine respectively; $D D A$ is the degree of deacetylation of chitosan (i.e. $78.6 \%) ; V^{*}{ }_{\mathrm{AgNO}}$ is the total volume of the titrant added at the endpoint of titration; and $1.7 \times 10^{-5}$ is the number of $\mathrm{AgNO}_{3}$ moles in $1 \mathrm{ml}$ of the titrant solution.

\section{The labeling of compounds}

FITC labeling of CMCh $\left(\mathrm{CMCh}^{\mathrm{FITC}}\right)$. The $\mathrm{CMCh}$ was conjugated with FITC according to (Geisberger et al. 2013) with slight modifications. Briefly, the solutions of CMCh $(32 \mathrm{mg})$ in distilled water $(3 \mathrm{ml})$ and FITC $(3 \mathrm{mg})$ in methanol $(5 \mathrm{ml})$ were mixed and stirred for $36 \mathrm{~h}$ in a dark at room temperature. Then the reaction mixture was dialyzed (Spectra/Por, cut off $6-8 \mathrm{kDa}$ ) against distilled water for 3 days, and freeze-dried.

FITC labeling of lysozyme $\left(\right.$ Lys $\left.^{\text {FITC }}\right)$. The FITClabeled lysozyme was prepared according to (Zhang et al. 2010). Briefly, $400 \mu \mathrm{l}$ of a freshly prepared solution of FITC $(1 \mathrm{mg} / \mathrm{ml})$ was dropped into $2.4 \mathrm{mg} / \mathrm{ml}$ of lysozyme in a $0.1 \mathrm{M}$ carbonate-bicarbonate buffer $(\mathrm{pH} 9)$. The reaction was carried out overnight in the dark at $4{ }^{\circ} \mathrm{C}$. 
The product was dialysed (Spectra/Por, cut off 6-8 kDa) against a PBS buffer ( $\mathrm{pH}$ 7.4) and freeze-dried. The molar ratio of FITC to Lys was 1, as determined using the protocol provided by the Sigma-Aldrich.

\section{Substrate preparation}

Gold-coated SPR chip, quartz, and round-shaped glass (with a diameter of $12 \mathrm{~mm}$ ) were firstly washed by sonication in methanol and then in water. All substrates were immersed in a $\mathrm{H}_{2} \mathrm{O}_{2} / \mathrm{NH}_{4} \mathrm{OH} / \mathrm{H}_{2} \mathrm{O}$ mixture $(1: 1: 5$ $\mathrm{vol} / \mathrm{vol} / \mathrm{vol}$ ) at $70{ }^{\circ} \mathrm{C}$ for $15 \mathrm{~min}$, then rinsed with water, dried, and exposed to air plasma for $10 \mathrm{~min}$. The gold surface of the SPR chips were then modified with selfassembled monolayers (SAM) using ACID-16. The SPR chip was kept in $1 \mathrm{mM}$ ACID-16 in ethanol in the dark for $24 \mathrm{~h}$, then rinsed with ethanol and water, and dried with nitrogen.

\section{LbL film preparation}

All cleaned substrates were immersed in $1 \mathrm{mg} / \mathrm{ml} \mathrm{CMCh}$ in $10 \mathrm{mM}$ PBS for 5 minutes, then rinsed with PBS, and immersed in $1 \mathrm{mg} / \mathrm{ml} \mathrm{Hep} \mathrm{in} \mathrm{PBS} \mathrm{for}$ 5 minutes. These steps were repeated to obtain the required number of layers.

\section{Surface analysis}

Surface plasmon resonance (SPR). The formation of $\mathrm{CMCh} / \mathrm{Hep} \mathrm{LbL}$ films and protein adsorption on SAM-modified chips (see Substrate preparation) was monitored in situ as a shift in the resonance wavelength using a custom-built SPR sensor (Institute of Photonics and Electronics, Academy of Sciences of the Czech Republic) at $25{ }^{\circ} \mathrm{C}$. The solutions of CMCh, PBS, and Heparin were subsequently pumped into the SPR flow cell with a flow rate of $25 \mu \mathrm{l} / \mathrm{min}$. The Hep- and CMCh-terminated LbL films were exposed to Alb (1 mg/ml in PBS), Lys ( $1 \mathrm{mg} / \mathrm{ml}$ in PBS), or FGF-2 (100 ng/ml in PBS) solutions for 30 or $90 \mathrm{~min}$, and then rinsed with PBS. The surface density (in $\mathrm{ng} / \mathrm{cm}^{2}$ ) of the particular proteins was calculated from a difference in resonance wavelength $\left(\Delta \lambda_{\text {res }}\right)$ registered in PBS before and after exposition to the protein solution; $\Delta \lambda_{\text {res }}=1 \mathrm{~nm}$ corresponds to the protein surface density of $15 \mathrm{ng} / \mathrm{cm}^{2}$ (Emmenegger et al. 2009).

UV-VIS Spectroscopy. The UV-Vis absorption spectra of $\mathrm{CMCh}^{\mathrm{FITC}} / \mathrm{Hep} \mathrm{LbL}$ films and $\mathrm{CMCh} / \mathrm{Hep} \mathrm{LbL}$ films with adsorbed $\mathrm{Alb}^{\text {FITC }}$ or Lys ${ }^{\text {FITC }}$ were recorded using a spectrophotometer Specord Plus (Analytik Jena). LbL films were deposited on quartz slides, then exposed to $1 \mathrm{mg} / \mathrm{ml}$ protein solution in PBS for $2 \mathrm{~h}$, then rinsed with PBS and dried in a stream of nitrogen before the measurement.

Atomic force microscopy (AFM). The surface topography of LbL films on glass cover slides was observed on Nanoscope IIIa, Digital Instruments in tapping mode with standard silicon cantilevers OTESPA7 (Veeco Instruments, a spring constant of $42 \mathrm{~N} / \mathrm{m}$ ) and a scan rate of $0.8-1 \mathrm{~Hz}$ in air.

\section{Results}

Characterization of cationically modified (quaternized) chitosan, CMCh

Chitosan was subjected to cationic modification with GTMAC. The occurrence of the reaction was confirmed by FTIR and ${ }^{1} \mathrm{H}$ NMR spectroscopies (see experimental section). The received product, $\mathrm{CMCh}$, showed good water solubility regardless of the $\mathrm{pH}$. The degree of substitution (DS) of $\mathrm{Ch}$ with GTMAC was determined using the conductometric titration of $\mathrm{CMCh}$ with $\mathrm{AgNO}_{3}$ (Fig. 1). Initially, the conductivity of the solution gradually decreased with the increasing volume of $\mathrm{AgNO}_{3}$ added as a result of the formation of an insoluble $\mathrm{AgCl}$ salt. The lowest solution conductivity, considered as the endpoint of the titration, was registered when all chlorate ions originated from the dissociation of trimethylammonium chloride were consumed by $\mathrm{Ag}^{+}$ ions from the titrant. The further addition of the titrant caused an increase in the solution's conductivity. The total volume of the $\mathrm{AgNO}_{3}$ solution added at the endpoint of titration (Fig. 1, $\mathrm{V}^{*}{ }_{\mathrm{AgNO}}$ ) was used to calculate DS from Equation 1. The substitution of Chitosan with GTMAC was $77.8 \%$.

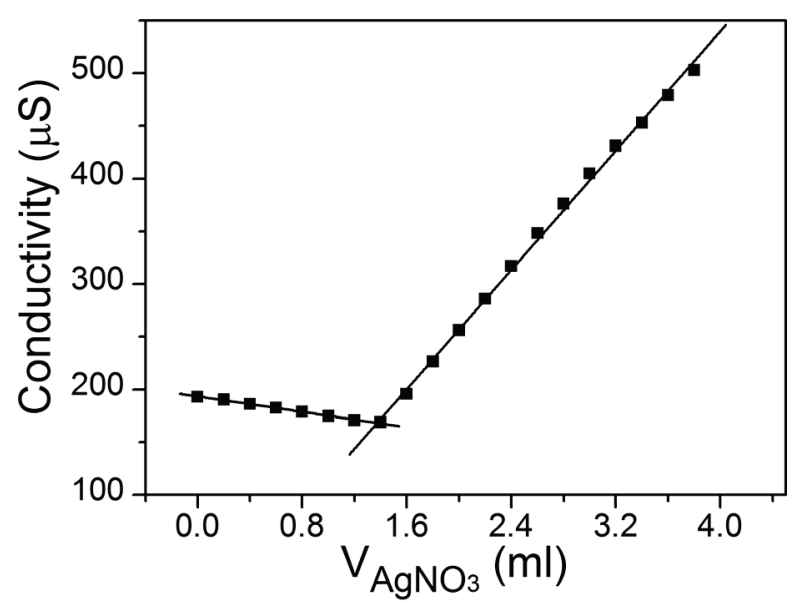

Fig. 1. Conductivity of $\mathrm{CMCh}$ as a function of volume of $\mathrm{AgNO}_{3}$ added. 


\section{The construction of CMCh/Hep LbL films}

The self-assembly process of $\mathrm{CMCh}$ and Hep was observed in situ using SPR. Figure 2 presents sensorgrams of the formation of a six-layer film terminated with Hep, $(\mathrm{CMCh} / \mathrm{Hep})_{3}$ (line 1), and a sevenlayer film terminated with $\mathrm{CMCh},(\mathrm{CMCh} / \mathrm{Hep})_{3} \mathrm{CMCh}$ (line 2). The SPR signal increased after each $\mathrm{CMCh}$ and hep deposition, demonstrating that both polysaccharides adsorbed in the LbL process. During the rinsing step, the signal initially decreased and then reached a constant level due to desorption of the loosely bound topmost polyelectrolyte molecules. The adsorption of Hep reached saturation after approximately 10 minutes. Interestingly, when $\mathrm{CMCh}$ was brought into contact with the Hepterminating layer, the signal first sharply increased and then continued to decrease. This phenomenon stopped and the SPR signal remained constant by replacing the $\mathrm{CMCh}$ solution with PBS. A difference in the resonance wavelength $\left(\Delta \lambda_{\text {res }}\right)$ in PBS before and after each adsorption step was plotted versus a number of the deposited layers (Fig. 2D). The $\Delta \lambda_{\text {res }}$ corresponds to the changes in the refractive index of the SPR chip surface and is proportional to the mass of adsorbed/desorbed compounds. The $\Delta \lambda_{\text {res }}$ increases with the increasing number of the layers in an exponential manner. This indicates that the amount of the adsorbed CMCh and Hep in each consecutive adsorption cycle is always higher than the amount of previously adsorbed polyelectrolytes. This observation was confronted with UV-Vis analysis. Figure $3 \mathrm{~A}$ shows the dependence of absorbance at $510 \mathrm{~nm}$ of the FITC-labeled $\mathrm{CMCh}, \mathrm{CMCh}^{\mathrm{FITC}}$, on a number of the deposited bilayers. The inset presents the UV-Vis spectra of a quartz plate coated up to five $\mathrm{CMCh}^{\mathrm{FITC}} / \mathrm{Hep}$ bilayers. The evolution of the absorbance with the number of the bilayers is well fitted by an exponential growth curve which is in line with the SPR findings.
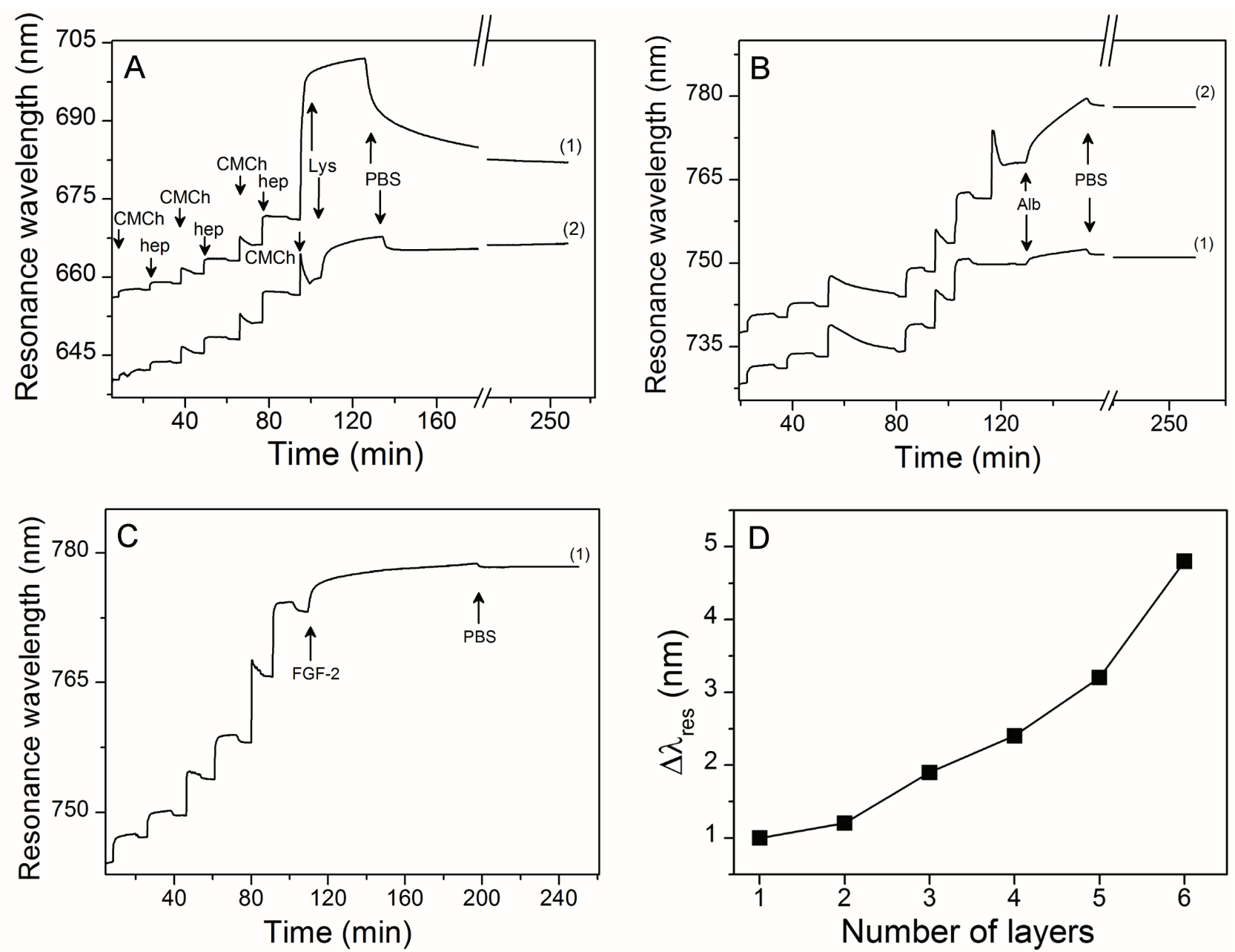

Fig. 2. In situ formation of (CMCh/Hep $)_{3}(1)$ and $(\mathrm{CMCh} / \mathrm{Hep})_{3} \mathrm{CMCh}(2) \mathrm{LbL}$ films observed by SPR. Arrows show the replacement of the solutions. The adsorption of Lys (1 mg/ml in PBS, A), Alb (1 mg/ml in PBS, B), and FGF-2 (100 ng/ml in PBS, C). Differences in the resonance wavelength shifts $\left(\Delta \lambda_{\text {res }}\right)$ as a function of the number of deposited layers (D). 
The LbL process was also followed by AFM. The topography of dry LbL films composed of 6-, 7- and 23-layers is presented in Figure 4. AFM images of the $(\mathrm{CMCh} / \mathrm{Hep})_{3}$ and $(\mathrm{CMCh} / \mathrm{Hep})_{3} \mathrm{CMCh}$ assemblies indicate the presence of characteristic granular structures, 'islets', that cover the whole surface of the substrate (Fig. 4D, E). The islets exhibit different sizes; smaller islets appear between the larger ones. Based on the crosssection graphs (Fig. 4A, B), the diameter and height of these islets reach up to $200 \mathrm{~nm}$ and $20 \mathrm{~nm}$, respectively. The surface features depended on the terminated layer of LbL films. The particular islets in the Hep-ending LbL film displayed a rough surface (Fig. 4D), whereas in the CMCh-ending LbL film, the islets became more compact, separated from each other by forming distinct edges (Fig. 4E). The morphology of the LbL films significantly changed when more bilayers were deposited. The surface of the $(\mathrm{CMCh} / \mathrm{Hep})_{11} \mathrm{CMCh} \mathrm{LbL}$ film exhibited large objects of $800 \mathrm{~nm}$ in diameter and about $30 \mathrm{~nm}$ in height (Fig. 4C, F). Also, the root mean squared surface roughness, $R_{q}$, increased from $6.0 \pm 0.1 \mathrm{~nm}$ to $9.7 \pm 0.8 \mathrm{~nm}$ for $(\mathrm{CMCh} / \mathrm{Hep})_{3} \mathrm{CMCh}$ and $(\mathrm{CMCh} / \mathrm{Hep})_{11} \mathrm{CMCh}$, respectively.

\section{The protein adsorption on CMCh/Hep LbL films}

The adsorption of Lys, Alb and FGF-2 on the LbL films was monitored in real time using SPR. The exposition of the Hep- and CMCh-terminated LbL film to Lys solution resulted in a signal shift of $30.8 \mathrm{~nm}$ and $7.8 \mathrm{~nm}$, respectively (Fig. 2A). However, when the Lys solution was replaced by PBS, a continuous decay of $\lambda_{\text {res }}$ over $2 \mathrm{~h}$ during rinsing with PBS was observed for $(\mathrm{CMCh} / \mathrm{Hep})_{3}$ (Fig. 2A, line 1). This indicates that about $60 \%$ of the initially loaded Lys into the $(\mathrm{CMCh} / \mathrm{Hep})_{3}$ assembly was released within $2 \mathrm{~h}$. On the contrary, $\lambda_{\text {res }}$ slightly decreased and remained stable during rinsing with PBS for $(\mathrm{CMCh} / \mathrm{Hep})_{3} \mathrm{CMCh}$ (Fig. 2A, line 2). Here, only $18 \%$ of the initially adsorbed Lys desorbed over $2 \mathrm{~h}$. Albumin exhibited the opposite behavior when contacted with the LbL films. A signal shift corresponding to Alb adsorption was 4.3 times higher for the $(\mathrm{CMCh} / \mathrm{Hep})_{3} \mathrm{CMCh}$ as compared to the $(\mathrm{CMCh} / \mathrm{Hep})_{3}$ film (Fig. 2B). The replacement of the Alb solution to PBS resulted in a $53 \%$ and $13 \%$ release of the initially loaded Alb from the $(\mathrm{CMCh} / \mathrm{Hep})_{3}$ and $(\mathrm{CMCh} / \mathrm{Hep})_{3} \mathrm{CMCh}$ films, respectively.

The $(\mathrm{CMCh} / \mathrm{Hep})_{3}$ film was used to physically capture FGF-2. The SPR sensorgram (Fig. 2C) demonstrates a stepwise increase in $\lambda_{\text {res }}$ during FGF-2
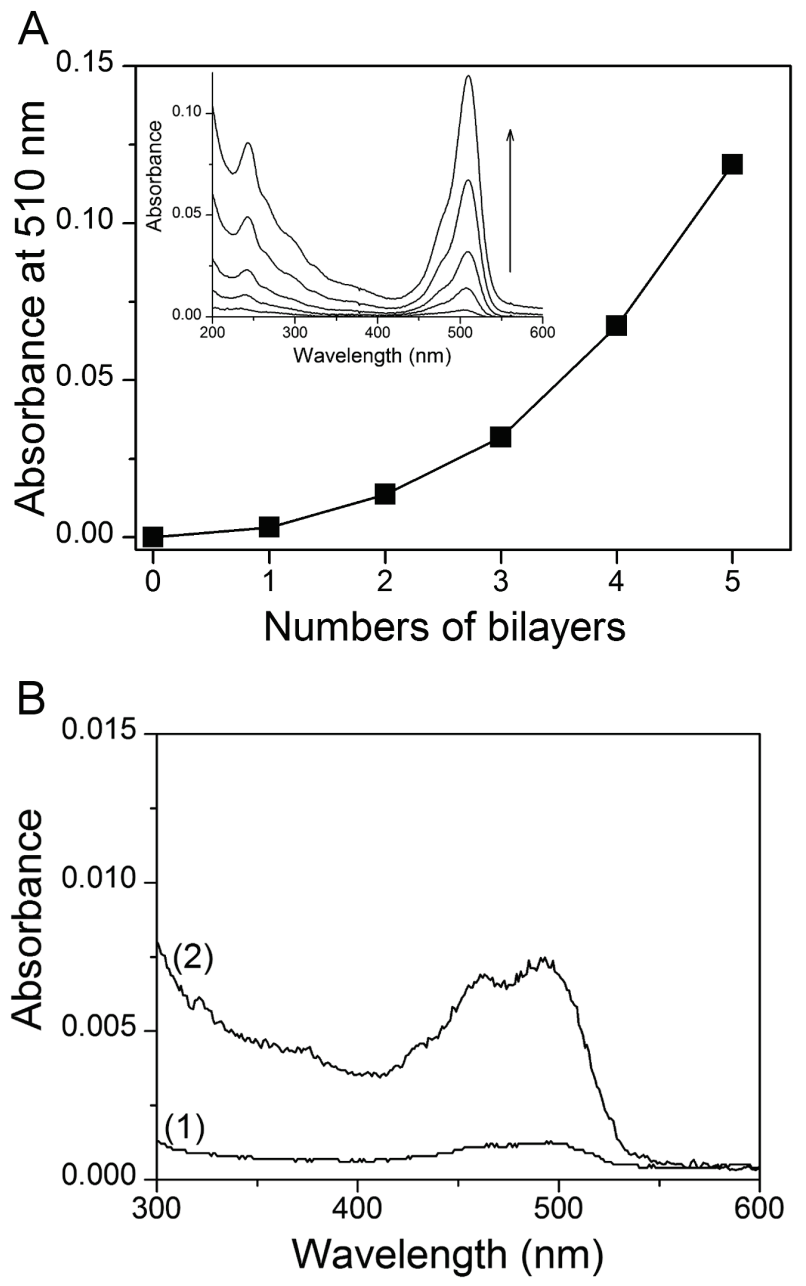

Fig. 3. The dependence of absorbance at $510 \mathrm{~nm}$ on the number of $\mathrm{CMCh}^{\mathrm{FTTC}} / \mathrm{Hep}$ bilayers (A). The inset shows the changes of the $\mathrm{CMCh}^{\mathrm{FTTC}}$ absorption spectra during the building of the $\mathrm{LbL}$ film. The absorption spectra (B) of Lys ${ }^{\mathrm{FTTC}}$ adsorbed on the $(\mathrm{CMCh} / \mathrm{Hep})_{3}$ assembly (line 1 ) and $\mathrm{Alb}^{\mathrm{FITC}}$ adsorbed on the (CMCh/Hep) ${ }_{3} \mathrm{CMCh}$ assembly (line 2 ).

adsorption. Then a slight decrease of the signal after rising with $\mathrm{PBS}$ corresponds to the $7 \%$ release of the initially adsorbed FGF-2.

The surface coverage by the proteins (see Surface analysis) was as follows: the $(\mathrm{CMCh} / \mathrm{Hep})_{3}$ assembly bound $19.5 \mathrm{ng} / \mathrm{cm}^{2}$ of $\mathrm{Alb}$ and $76.5 \mathrm{ng} / \mathrm{cm}^{2}$ of FGF-2 whereas the $(\mathrm{CMCh} / \mathrm{Hep})_{3} \mathrm{CMCh}$ assembly bound $117 \mathrm{ng} / \mathrm{cm}^{2}$ of Lys and $148.5 \mathrm{ng} / \mathrm{cm}^{2}$ of Alb. The correct determination of the lysozyme surface density on the $(\mathrm{CMCh} / \mathrm{Hep})_{3}$ assembly was impossible due to continuous Lys desorption from the film (Fig. 2A, line 1).

Protein adsorption was also studied by UV-Vis spectroscopy. The FITC absorption band indicates the presence of $\mathrm{Lys}^{\mathrm{FITC}}$ on the $(\mathrm{CMCh} / \mathrm{Hep})_{3}$ assembly (Fig. 3B, spectra 1) and $\mathrm{Alb}^{\mathrm{FITC}}$ on the $(\mathrm{CMCh} / \mathrm{Hep})_{3} \mathrm{CMCh}$ assembly (Fig. 3B, spectra 2$)$. There 

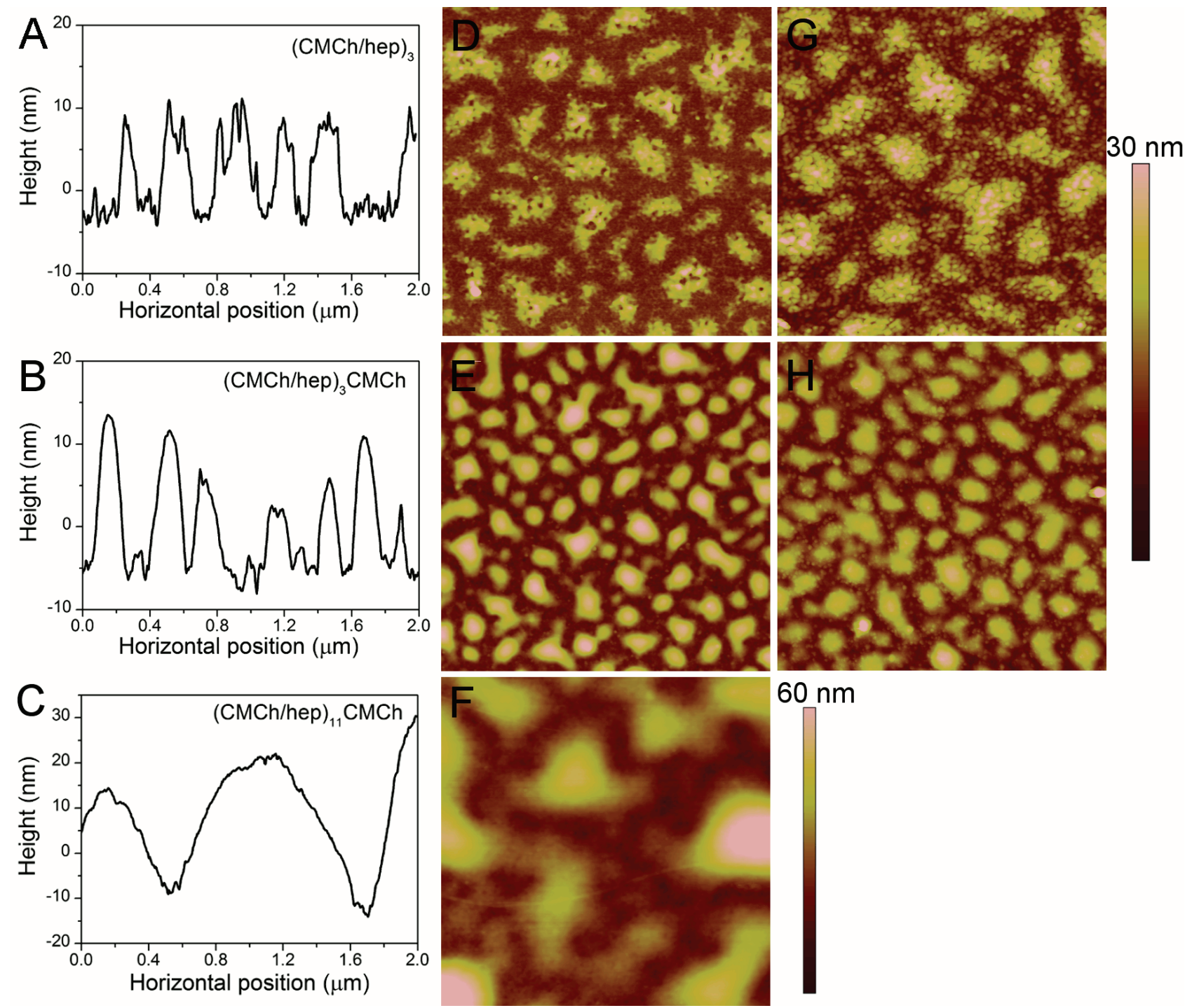

$60 \mathrm{~nm}$

Fig. 4. AFM cross-sectional height and topography of the (CMCh/Hep) $)_{3}(\mathbf{A}, \mathbf{D})$, (CMCh/Hep) ${ }_{3} \mathrm{CMCh}(\mathbf{B}, \mathbf{E})$ and $(\mathrm{CMCh} / \mathrm{Hep})_{11} \mathrm{CMCh}$ $(\mathbf{C}, \mathbf{F})$ assemblies. AFM images of $(\mathrm{CMCh} / \mathrm{Hep})_{3}$ and $(\mathrm{CMCh} / \mathrm{Hep})_{3} \mathrm{CMCh}$ assemblies after exposure to lysozyme $(\mathbf{G})$ and albumin $(\mathbf{H})$. Image size: $2 \times 2 \mu \mathrm{m}$; the $z$ scale: $30 \mathrm{~nm}$ or $60 \mathrm{~nm}$ shown on the right site of the image.

was no evidence of $\mathrm{Lys}^{\mathrm{FITC}}$ on $(\mathrm{CMCh} / \mathrm{Hep})_{3} \mathrm{CMCh}$ and $\mathrm{Alb}^{\mathrm{FITC}}$ on $(\mathrm{CMCh} / \mathrm{Hep})_{3}$ assemblies (data not shown).

Changes in the surface topography after the adsorption of Alb and Lys were studied by AFM. Many small dots with a diameter of approx. $10 \mathrm{~nm}$ appeared after protein adsorption and they covered both the islets and the space between the islets (Fig. 4G, H). Nevertheless, the surface roughness $\mathrm{R} q$ did not change.

\section{Discussion}

In the present work, the quaternized chitosanand heparin-terminated multilayer films were studied for their ability to adsorb proteins of differing isoelectric points. The buildup of the $\mathrm{CMCh} / \mathrm{Hep}$ multilayer films was followed by SPR and UV-Vis spectroscopy (Fig. 2 and 3). The results demonstrated that the LbL film grew in an exponential-like fashion (Fig. 2D and 3A). Furthermore, the SPR sensorgram (Fig. 2A, B, C) showed a characteristic 'peaked' evolution of $\lambda_{\text {res }}$ when the Hepterminated film was brought into contact with the $\mathrm{CMCh}$ solution. This phenomenon has already been reported in the literature (Richert et al. 2004, Picart et al. 2001, Lavalle et al. 2004) and was explained by diffusion of the polyelectrolyte in and out of the film during the LbL buildup process. Confocal laser microscopy has proved that a fluorescently labeled chitosan migrated inside chitosan/hyaluronan multilayer films during their formation (Richert et al. 2004). This, in turn, results in exponential growth of the LbL film.

The AFM images of the LbL films showed the presence of the granular structures in the form of so- 
called 'islets' which might result from the coacervation of both oppositely charged polyelectrolytes (Fig. 4D, E). These islets coalesced and formed larger sized structures as the number of deposited layers increased (Fig. 4F). Similar topographical features revealed LbL films composed of, e.g. poly(L-lysine) and hyaluronan (Picart et al. 2001), chitosan and hyaluronan (Cardoso et al. 2016), chitosan and poly( $\gamma$-glutamic acid) (Zhao et al. 2016). The islets' formation was explained by the aggregation of the polyelectrolytes at a substrate surface during the deposition cycles. The islets became larger with the increasing number of bilayers which is in line with our observation.

The interaction of the $\mathrm{CMCh} / \mathrm{Hep}$ films with lysozyme and albumin were studied by SPR, UV-Vis and AFM. The adsorption of those proteins strongly depended on the terminating polysaccharide. Lysozyme $\left(\mathrm{I}_{p}=11.4\right)$, bearing a net positive charge at $\mathrm{pH} 7.4$, was ionically attracted by the negatively charged Hep-terminated film (Fig. 2A). On the contrary, the negatively charged Alb $\left(\mathrm{I}_{p}=4.9\right)$ adsorbed effectively on the positively CMChterminated film (Fig. 2B). If the topmost polysaccharide layer and protein were like-charged, the adsorption of protein on the film was minimized due to the electrostatic repulsion (Fig. 2A, B). It is evident that the adsorption of Lys and Alb was mainly driven by the electrostatic interactions with the terminal layer of the polysaccharide LbL film. A similar conclusion was drawn by (Hoven et al. 2007) who studied the behavior of several proteins on chitosan-based coatings. The negatively charged sulfonate-functionalized chitosan films suppressed the adsorption of the same charged proteins, i.e. albumin and fibrinogen, and electrostatically attracted the positively charged ribonuclease and lysozyme. Beykal et al. (2015) indicated that the electrostatic interactions played a key role in the adsorption of Alb to charged and uncharged gold surfaces. An increased mass adsorption was observed when the protein and the surface were oppositely charged, which is also confirmed by our results.

Based on the SPR data, protein adsorption also occurred on the alike-charged surface although to a lesser extent (Fig. 2A, B). It is worth noting that a globular protein like Lys and Alb, cannot be considered as a single charged point, since the surface of protein consists of positively and negatively charged domains that can interact with the LbL film (Cooper et al. 2005). Further, as observed in the AFM images (Fig. 4), both polysaccharides form complexes upon assembling on the surface. Such polyelectrolyte complexes destroy the layer structure of the film and can undergo dynamic structural changes resulting from $\mathrm{CMCh}$ diffusion within the film. Thus, regardless of the last deposited layer, both polysaccharides can be accessible at the surface, and consequently, they can electrostatically interact with the protein molecules to some extent.

Both proteins demonstrated almost irreversible binding to the positively charged $(\mathrm{CMCh} / \mathrm{Hep})_{3} \mathrm{CMCh}$ film (Fig. 2A, B, line 2). By contrast, the (CMCh/Hep) 3 film showed a reversible loading of Lys and Alb; the proteins were significantly released over $2 \mathrm{~h}$ of rinsing with PBS (Fig. 2A, B, line 1). This suggests that heparin exhibits a low binding affinity to both proteins. As reported, Lys binds to heparin with a dissociation constant $\left(\mathrm{K}_{d}\right)$ of $1.3 \times 10^{-5} \mathrm{M}$, that is 100 -fold higher than $\mathrm{K}_{d}$ determined for unsulfated glycosaminoglycans (GAGs), e.g. hyaluronic acid (Vandamme et al. 1994). This indicates that the sulfate groups of GAGs were not dominant in the interaction with the positively charged Lys.

A number of studies have shown the applicability of LbL films as reservoirs of fragile biomolecules and therapeutics (Kumorek et al. 2015, Monge et al. 2015). Based on the results obtained from the interactions of Lys with the LbL films, the $(\mathrm{CMCh} / \mathrm{Hep})_{3}$ assembly was selected to physically capture the positively charged biomolecule FGF-2. The exposure of the Hep-terminated film to the FGF-2 solution yielded $76.5 \mathrm{ng} / \mathrm{cm}^{2}$ of the stably immobilized FGF-2; only $7 \%$ of the initially loaded FGF-2 was released after a $2 \mathrm{~h}$ rinsing with PBS. In fact, FGF-2 possesses strong binding affinity to sulfated GAGs, such as heparin (Faham et al. 1996). Therefore, not only the electrostatic attractions, but also H-bond formation with electronegative atoms of Hep contributed to the FGF-2 adsorption process and stabilized the FGF-2-heparin complex (Schlessinger et al. 2000). This could explain the different behavior of both positively charged FGF-2 and Lys on the Hep-terminated LbL film.

The AFM imaging also proved the proteins adsorption on the LbL films. The small granules originating from the immobilized Lys and Alb were clearly visible on the whole surface of the $(\mathrm{CMCh} / \mathrm{Hep})_{3}$ and (CMCh/Hep) ${ }_{3} \mathrm{CMCh}$ LbL films (Fig. 4G, H). Previously, Ladam et al. (2000) reported that albumin self-aggregated and formed a dense multimolecular layer on the positively charged polystyrenesulfonate/polyallylamine LbL film. Similarly, Gergely et 
al. (2004) found the formation of a thick layer of albumin exceeding the dimension of the native protein on the poly(L-lysine)/poly(glutamic acid) LbL film. However, from the AFM images, it is difficult to conclude if the proteins adsorbed in a monolayer or multilayer mode.

\section{Conclusions}

Herein, we studied the behavior of model proteins on the surface of the self-assembled quaternized chitosan (CMCh)/heparin multilayer film. Polysaccharide films forming via the layer-by-layer (LbL) method displayed an exponential growth at a neutral $\mathrm{pH}$. The CMCh- or hep- terminated LbL films interacted with albumin and lysozyme regardless of the charge of the outermost layer. However, since protein adsorption was driven mainly by the electrostatic interaction, the amount of the adsorbed protein depended on the terminating polysaccharide. Both proteins were almost irreversibly bound to the positively charged CMCh-terminated LbL film, $(\mathrm{CMCh} / \mathrm{Hep})_{3} \mathrm{CMCh}$. Whereas, the Hep-terminated film, $(\mathrm{CMCh} / \mathrm{hHep})_{3}$, was more resistant to the albumin adsorption and demonstrated a relatively weak interaction with lysozyme. On the other hand, the $(\mathrm{CMCh} / \mathrm{Hep})_{3} \mathrm{LbL}$ film effectively bound FGF-2. Owing to that strong binding affinity to growth factors, the hep-terminated LbL film can be applied as a biofunctional surface coating bearing therapeutic proteins, such as FGF-2, for biomedical applications.

\section{Conflict of Interest}

There is no conflict of interest.

\section{Acknowledgements}

This work was supported by the Ministry of Education, Youth and Sports of CR within the National Sustainability Program II, Project BIOCEV-FAR LQ1604.

\section{References}

ALMODOVAR J, BACON S, GOGOLSKI J, KISIDAY JD, KIPPER MJ: Polysaccharide-based polyelectrolyte multilayer surface coatings can enhance mesenchymal stem cell response to adsorbed growth factors. Biomacromolecules 11: 2629-2639, 2010.

ARIGA K, YAMAUCHI Y, RYDZEK G, JI QM, YONAMINE Y, WU KCW, HILL JP: Layer-by-layer Nanoarchitectonics: Invention, innovation, and evolution. Chem Lett 43: 36-68, 2014.

BEYKAL B, HERZBERG M, OREN Y, MAUTER MS: Influence of surface charge on the rate, extent, and structure of adsorbed Bovine Serum Albumin to gold electrodes. J Colloid Interface Sci 460: 321-328, 2015.

CARDOSO MJ, CARIDADE SG, COSTA RR, MANO JF: Enzymatic Degradation of polysaccharide-based layer-bylayer structures. Biomacromolecules 17: 1347-1357, 2016.

CHO J, GRANT J, PIQUETTE-MILLER M, ALLEN C: Synthesis and physicochemical and dynamic mechanical properties of a water-soluble chitosan derivative as a biomaterial. Biomacromolecules 7: 2845-2855, 2006.

COOPER CL, DUBIN PL, KAYITMAZER AB, TURKSEN S: Polyelectrolyte-protein complexes. Curr Opin Colloid Interface Sci 10: 52-78, 2005.

DEPHILLIPS P, LENHOFF AM: Relative retention of the fibroblast growth factors FGF-1 and FGF-2 on strong cationexchange sorbents. J Chromatogr A 1036: 51-60, 2004.

EMMENEGGER CR, BRYNDA E, RIEDEL T, SEDLAKOVA Z, HOUSKA M, ALLES AB: Interaction of blood plasma with antifouling surfaces. Langmuir 25: 6328-6333, 2009.

FAHAM S, HILEMAN RE, FROMM JR, LINHARDT RJ, REES DC: Heparin structure and interactions with basic fibroblast growth factor. Science 271: 1116-1120, 1996.

FOLLMANN HDM, MARTINS AF, GEROLA AP, BURGO TAL, NAKAMURA CV, RUBIRA AF, MUNIZ EC: Antiadhesive and antibacterial multilayer films via layer-by-layer assembly of TMC/Heparin complexes. Biomacromolecules 13: 3711-3722, 2012.

GEISBERGER G, GYENGE EB, MAAKE C, PATZKE GR: Trimethyl and carboxymethyl chitosan carriers for bioactive polymer-inorganic nanocomposites. Carbohydr Polym 91: 58-67, 2013.

GERGELY C, BAHI S, SZALONTAI B, FLORES H, SCHAAF P, VOEGEL JC, CUISINIER FJG: Human serum albumin self-assembly on weak polyelectrolyte multilayer films structurally modified by $\mathrm{pH}$ changes. Langmuir 20: 5575-5582, 2004. 
GRIBOVA V, AUZELY-VELTY R, PICART C: Polyelectrolyte multilayer assemblies on materials surfaces: From cell adhesion to tissue engineering. Chem Mater 24: 854-869, 2012.

HOVEN VP, TANGPASUTHADOL V, ANGKITPAIBOON Y, VALLAPA N, KIATKAMJORNWONG S: Surfacecharged chitosan: Preparation and protein adsorption. Carbohyd Polym 68: 44-53, 2007.

KASAAI MR, ARUL J, CHARLET C: Intrinsic viscosity-molecular weight relationship for chitosan. J Polym Sci B Polym Phys 38: 2591-2598, 2000.

KUMOREK M, KUBIES D, FILOVA E, HOUSKA M, KASOJU N, MAZL CHANOVA E, MATEJKA R, KRYSLOVA M, BACAKOVA L, RYPACEK F: Cellular responses modulated by FGF-2 Adsorbed on Albumin/Heparin Layer-by-Layer assemblies. PLoS One 10: e0125484, 2015.

LADAM G, GERGELY C, SENGER B, DECHER G, VOEGEL JC, SCHAAF P, CUISINIER FJG: Protein interactions with polyelectrolyte multilayers: Interactions between human serum albumin and polystyrene sulfonate/polyallylamine multilayers. Biomacromolecules 1: 674-687, 2000.

LAVALLE P, PICART C, MUTTERER J, GERGELY C, REISS H, VOEGEL JC, SENGER B,SCHAAF P: Modeling the buildup of polyelectrolyte multilayer films having exponential growth. J Phys Chem B 108: 635-648, 2004.

MONGE C, ALMODOVAR J, BOUDOU T, PICART C: Spatio-temporal control of LbL films for biomedical applications: From 2D to 3D. Adv Healthc Mater 4: 811-830, 2015.

PICART C, LAVALLE P, HUBERT P, CUISINIER FJG, DECHER G, SCHAAF P,VOEGEL JC: Buildup mechanism for poly(L-lysine)/hyaluronic acid films onto a solid surface. Langmuir 17: 7414-7424, 2001.

RICHERT L, LAVALlE P, PAYAN E, SHU XZ, PRESTWICH GD, STOLTZ JF, SCHAAF P, VOEGEL JC, PICART C: Layer by layer buildup of polysaccharide films: Physical chemistry and cellular adhesion aspects. Langmuir 20: 448-458, 2004.

SALLOUM DS, SCHLENOFF JB: Protein adsorption modalities on polyelectrolyte multilayers. Biomacromolecules 5 : 1089-1096, 2004.

SCHLESSINGER J, PLOTNIKOV AN, IBRAHIMI OA, ELISEENKOVA AV, YEH BK, YAYON A, LINHARDT RJ, MOHAMMADI M: Crystal structure of a ternary FGF-FGFR-heparin complex reveals a dual role for heparin in FGFR binding and dimerization. Mol Cell 6: 743-750, 2000.

VANDAMME MPI, MOSS JM, MURPHY WH, PRESTON BN: Binding properties of glycosaminoglycans to lysozyme-effect of salt and molecular weight. Arch Biochem Biophys 310: 16-24, 1994.

VOLPATO FZ, ALMODOVAR J, ERICKSON K, POPAT KC, MIGLIARESI C, KIPPER MJ: Preservation of FGF-2 bioactivity using heparin-based nanoparticles, and their delivery from electrospun chitosan fibers. Acta Biomater 8: 1551-1559, 2012.

WANG X, LIU T, CHEN Y, ZHANG K, MAITZ MF, PAN CJ, CHEN JY, HUANG N: Extracellular matrix inspired surface functionalization with heparin, fibronectin and VEGF provides an anticoagulant and endothelialization supporting microenvironment. Appl Surf Sci 320: 871-882, 2014.

WIARACHAI O, THONGCHUL N, KIATKAMJORNWONG S, HOVEN VP: Surface-quaternized chitosan particles as an alternative and effective organic antibacterial material. Colloids Surf B Biointerfaces 92: 121-129, 2012.

ZHANG DM, ANSAR SM, VANGALA K, JIANG DP: Protein adsorption drastically reduces surface-enhanced Raman signal of dye molecules. J Raman Spectrosc 41: 952-957, 2010.

ZHAO N, YANG C, WANG Y, ZHAO B, BIAN F, LI X, WANG J: Probing the surface microstructure of layer-bylayer self-assembly chitosan/poly(l-glutamic acid) multilayers: A grazing-incidence small-angle X-ray scattering study. Mater Sci Eng C Mater Biol Appl 58: 352-358, 2016. 